\title{
Fasting plasma magnesium concentrations and glucose disposal in diabetes
}

\author{
C S YAJNIK, R F SMITH, T D R HOCKADAY, N I WARD
}

\begin{abstract}
Fasting plasma concentrations of magnesium were measured by neutron activation analysis in 30 nondiabetics and 87 diabetics (55 non-insulin-treated, 32 insulin treated). Plasma concentrations of magnesium were lowest in the insulin treated group (mean 0.84 (SEM 0.01) $\mathrm{mmol} / 1 ; 2.0(0.02) \mathrm{mg} / 100 \mathrm{ml})$, intermediate in the non-diabetics (mean 0.89 (SEM 0.01) mmol/1; $2.2(0.02) \mathrm{mg} / 100 \mathrm{ml})$, and highest in the non-insulintreated diabetics (mean 0.95 (SEM 0.02) mmol/1; 2.3 $(0.05) \mathrm{mg} / 100 \mathrm{ml})$. In all diabetics plasma magnesium concentrations were inversely related to plasma glucose values $\left(r_{s}=-0.33 ; p<0.01\right)$ and in non-insulin-treated patients to plasma insulin concentrations $\left(r_{s}=-0.28\right.$; $p<0.05$ ), the former confirming previous observations. In 67 of the diabetics the $K_{G}$ constant for disposal rate of glucose during a standard intravenous glucose tolerance test was directly related to fasting plasma magnesium concentrations, and this relation persisted after controlling for age, sex, body mass index, type of treatment, and glucose and insulin values.

This direct relation of plasma magnesium concentration with glucose disposal was unexplained by its influence on insulin secretion but was related to insulin sensitivity; hence magnesium may be an important determinant of insulin sensitivity in maturity onset diabetes.
\end{abstract}

\section{Introduction}

Magnesium is an essential element ${ }^{1}$ and is a cofactor in both glucose transporting mechanisms of cell membranes ${ }^{2}$ and various enzymes important in carbohydrate oxidation. ${ }^{3}$ It also plays a part in mechanisms for energy transfer mediated by phosphate bonds. ${ }^{3}$ The concentrations of magnesium in the serum of healthy people are remarkably constant. ${ }^{4}$ Diabetic patients may develop hypomagnesaemia, ${ }^{5} 6$ possibly because excessive urinary loss of magnesium accompanies glycosuria. ${ }^{7} 8$ Hypomagnesaemia has been claimed as a risk factor for diabetic retinopathy ${ }^{9}$ and to produce insulin resistance after diabetic ketoacidosis. ${ }^{10}$ A deficient supply of magnesium in areas with soft water may be a risk factor for ischaemic heart disease. ${ }^{11} 12$

From random clinic samples ${ }^{6}$ and diurnal profiles of diabetics and non-diabetics, ${ }^{13}$ Mather et al discovered an inverse correlation between plasma concentrations of magnesium and glucose. We do not know, however, whether plasma magnesium affects the disposal of glucose loads from the blood, nor whether it is

Sheikh Rashid Diabetes Unit, Radcliffe Infirmary, Oxford OX2 6HE C S YAJNIK, MD, honorary registrar

R F SMITH, FIMLS, chief scientific officer

T D R HOCKADAY, DPHIL, FRCP, consultant physician

Imperial College Reactor Centre, Silwood Park, Ascot N I WARD, PHD, research associate

Correspondence to: Dr T D R Hockaday. related to the plasma insulin concentration. We have therefore studied plasma magnesium concentrations in diabetic patients, both fasting and after intravenous glucose.

\section{Subjects and methods}

Table I gives clinical and laboratory data on the 87 diabetics and 30 non-diabetics who agreed to cooperate in the study. Thirty two diabetic subjects were receiving insulin at the time of study; of the remaining 55, non-insulin-treated diabetics, 43 were taking oral sulphonylureas and 12 were being managed by diet alone. All subjects had normal liver function values, two had a plasma creatinine concentration above $150 \mu \mathrm{mol} / 1(1.7 \mathrm{mg} / 100 \mathrm{ml})$, but none had clinically detectable proteinuria. Three patients were receiving thiazide diuretics.

TABLE I-Basic information on subjects studied. Values are means (SEM in parentheses)

\begin{tabular}{|c|c|c|c|c|}
\hline & $\begin{array}{c}\text { Non- } \\
\text { diabetics } \\
(n=30)\end{array}$ & $\begin{array}{l}\text { Insulin } \\
\text { treated } \\
\text { diabetics } \\
(n=32)\end{array}$ & $\begin{array}{c}\text { Non-insulin- } \\
\text { treated } \\
\text { diabetics } \\
(n=55)\end{array}$ & $\begin{array}{c}\text { All } \\
\text { diabetics } \\
(\mathrm{n}=87)\end{array}$ \\
\hline \multirow{5}{*}{$\begin{array}{l}\text { Age (years) } \\
\text { Men (\%) } \\
\text { Body mass index } \\
\quad \text { (weight in } \mathrm{kg} / \mathrm{height} \\
\left.\text { in } \mathrm{m}^{2}\right) \\
\text { Glucose }(\mathrm{mmol} / \mathrm{l}) \\
\text { Insulin }(\mathrm{mU} / \mathrm{l}) \\
\mathrm{HbA}_{\mathrm{lc}}(\%) \\
\mathrm{K}_{\mathrm{G}} \dagger \\
\text { Magnesium }(\mathrm{mmol} / \mathrm{l})\end{array}$} & $\begin{array}{c}46 \cdot 5(2 \cdot 3) \\
56\end{array}$ & $\begin{array}{c}45 \cdot 9(2 \cdot 7) \\
59\end{array}$ & $\begin{array}{c}59 \cdot 7(1 \cdot 1)^{* *} \\
76^{*}\end{array}$ & $\begin{array}{c}54 \cdot 7(1 \cdot 4)^{* *} \\
70^{*}\end{array}$ \\
\hline & $22.9(0.8)$ & 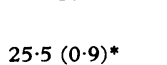 & 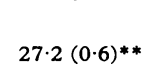 & 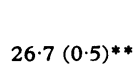 \\
\hline & & & $\begin{array}{l}8.1(0.4) \\
8.1(0.7)\end{array}$ & $0.8(0.5)$ \\
\hline & & $\begin{array}{l}12.2(0.6) \\
0.55(0.05)\end{array}$ & $\begin{array}{c}10.0(0.4) \\
0.80(0.05)\end{array}$ & $\begin{array}{c}10.8(0.4) \\
0.70(0.04)\end{array}$ \\
\hline & $0.89(0.01)$ & & & \\
\hline
\end{tabular}

All concentrations except $\mathrm{HbA}_{1 \mathrm{c}}$ measured in fasting blood plasma.

Compared with non-diabetics: $* p<0.05 ; * * p<0.01$.

$+K G=$ Rate constant for decrease of glucose during intravenous glucose tolerance test.

Conversion: SI to traditional units-Glucose: $1 \mathrm{mmol} / 1 \approx 18 \mathrm{mg} / 100 \mathrm{ml}$. Magnesium $1 \mathrm{mmol} / 1 \approx 2.4 \mathrm{mg} / 100 \mathrm{ml}$.

Blood samples from fasting subjects were collected in special lithium heparin containers for elemental analysis and separately for glucose, insulin, and "metabolite" measurements. Patients did not take their antidiabetic treatment on the morning of the test. Sixty seven of the diabetics were given an intravenous glucose tolerance test, $50 \%$ glucose solution ( $20 \mathrm{~g}$ glucose $/ \mathrm{m}^{2}$ body surface) being injected intravenously over two minutes. This test was done three or five years after diagnosis as part of a prospective study on a larger group of diabetics.

Plasma magnesium concentration was determined by neutron activation analysis using the ${ }^{27} \mathrm{Mg}$ nuclide (half life 9.5 minutes, $\gamma$ ray energies $843,1014 \mathrm{keV}$ ) after the elimination of sodium with hydrated antimony pentoxide. ${ }^{14}$ The coefficient of variation for 10 replicate analyses of "pooled" blood plasma was $7 \%$, and there was $101 \%$ recovery of magnesium added to the pooled sample at a concentration of $0.82 \mathrm{mmol} / 1(2.0 \mathrm{mg} / 100 \mathrm{ml})$. Fasting plasma samples were similarly collected for elemental analysis from 30 non-diabetics for comparison.

Plasma glucose concentration was measured on an autoanalyser by the glucose oxidase (gum guaiac) method of Technicon Instruments (Tarrytown, USA), and metabolites were measured as described. ${ }^{15}$ Plasma insulin was measured by radioimmunoassay. ${ }^{16}$ Haemoglobin $\mathrm{A}_{1 \mathrm{c}}\left(\mathrm{HbA}_{1 \mathrm{c}}\right)$ was measured by an isoelectrofocusing method with a five hour incubation of the dialysed sample at $37^{\circ} \mathrm{C}$ to exclude short term glucose adducts. ${ }^{17}$ The rate constant $\left(\mathrm{K}_{\mathrm{G}}\right)$ for decline in blood glucose during an intravenous glucose tolerance test was calculated from plasma glucose values from 10 to 60 minutes after intravenous injection of glucose. ${ }^{18}$ The insulin resistance factor was calculated 
from fasting glucose and insulin values ${ }^{19}$; this factor is a quantitative expression of a person's resistance to the action of insulin, an arbitrary scale being used on which normal, non-diabetic subjects have a value of 1 or less.

Results are expressed as means and SEM and were analysed either by Student's $t$ test (unpaired or paired) or non-parametrically by Spearman's correlation coefficient $\left(r_{s}\right)$. Multiple linear regression analysis was performed on an ICL 2980 computer according to the program of the statistical package for the social sciences, ${ }^{20}$ the data having been normalised as necessary by appropriate mathematical conversions.

\section{Results}

The fasting plasma magnesium concentration was lower in the insulin treated and higher in the non-insulin-treated diabetics than in the non-diabetic subjects (table I). Magnesium concentration was positively correlated with age when results for both groups of diabetics were pooled (table II); among the non-insulin-treated patients women had a lower magnesium concentration than men $(p<0.05)$. The plasma magnesium concentrations in two subjects with raised plasma creatinine values and three subjects receiving thiazide diuretics were comparable to those of the rest of the group.

TABLE II-Correlation of fasting magnesium values with other factors

\begin{tabular}{|c|c|c|c|c|}
\hline & Non-diabetics & $\begin{array}{l}\text { Insulin } \\
\text { treated } \\
\text { diabetics }\end{array}$ & $\begin{array}{l}\text { Non-insulin- } \\
\text { treated } \\
\text { diabetics }\end{array}$ & $\begin{array}{c}\text { All } \\
\text { diabetics }\end{array}$ \\
\hline 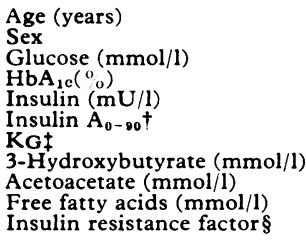 & $\begin{array}{l}0 \cdot 11 \\
0.13\end{array}$ & $\begin{array}{c}0.33 \\
0.22 \\
-0.28 \\
-0.55 * * \\
\\
0.09 \\
0.06 \\
-0.07 \\
0.13\end{array}$ & $\begin{array}{l}0.02 \\
-0.28^{*} \\
-0.21 \\
-0.25 \\
-0.28^{*} \\
-0.002 \\
0.22 \\
-0.10 \\
-0.14 \\
-0.06 \\
-0.36^{* *}\end{array}$ & $\begin{aligned} & 0.33^{* *} \\
- & 0.17 \\
- & 0.33^{* *} \\
- & 0.44^{* * *}\end{aligned}$ \\
\hline
\end{tabular}

Metabolites refer to fasting concentrations in blood plasma for glucose, insulin free fatty acids, and magnesium, and whole blood for 3-hydroxybutyrate and acetoacetate.

Inverse correlation with sex denotes lower values in women.

$p<0.05 ;{ }^{* *} p<0.01 ; * * * p<0.001$ (Spearman's correlation coefficient).

Insulin $\mathrm{A}_{0-90}$ refers to total area under insulin $v$ time curve for 90 minutes after intravenous injection of glucose.

KG = Rate factor for disappearance of glucose from plasma.

Conversion: SI to traditional units-Glucose: $1 \mathrm{mmol} / 1 \approx 18 \mathrm{mg} / 100 \mathrm{ml}$. 3-Hydro-

Conversion: 1 to traditional units-Glucose: $1 \mathrm{mmol} / 1 \approx 18 \mathrm{mg} / 100.2 \mathrm{mg} / 100 \mathrm{ml}$

Free fatty acids : $1 \mathrm{mmol} / \mathrm{l} \approx 25.6 \mathrm{mg} / 100 \mathrm{ml}$.

Plasma concentrations of magnesium and glucose were inversely correlated, as were those of magnesium and $\mathrm{HbA}_{1 c}$ (table II). In the whole diabetic group there was a direct correlation between magnesium and the rate of decrease in glucose after its injection (as measured by the $\mathrm{K}_{\mathrm{G}}$ rate constant) (see figure). This relation between magnesium and $\mathrm{K}_{\mathrm{G}}$ was not secondary to the original relation between magnesium and glucose and the known inverse relation between fasting glucose and $\mathrm{K}_{\mathrm{G}}$ because it remained significant, even when the interaction of each factor with glucose had been allowed for $(\mathrm{r}=0.32 ; \mathrm{p}<0.01)$.

Plasma magnesium concentration was inversely related to the fasting plasma insulin value in non-insulin-treated patients (table II) but not to the total secretion of insulin during the intravenous glucose tolerance test. The relation with fasting insulin was in part secondary to the relation of both to the degree of obesity. The plasma concentration of magnesium was inversely related to those of the ketone bodies 3-hydroxybutyrate and acetoacetate. It was, however, not related to free fatty acid concentrations.

Because of the interrelations of the various factors listed above multiple linear regression analysis of the $\mathrm{K}_{\mathrm{G}}$ rate constant was performed. For all the diabetics the link between plasma magnesium concentration and the $K_{G}$ rate factor remained significant $(p<0.05)$, even with allowance for interactions with the mode of treatment of diabetes, age, sex, body mass index, and the concentrations of glucose and ketone bodies.

The plasma magnesium concentration fell by about $4 \%$ during the intravenous glucose tolerance test but this was not statistically significant.

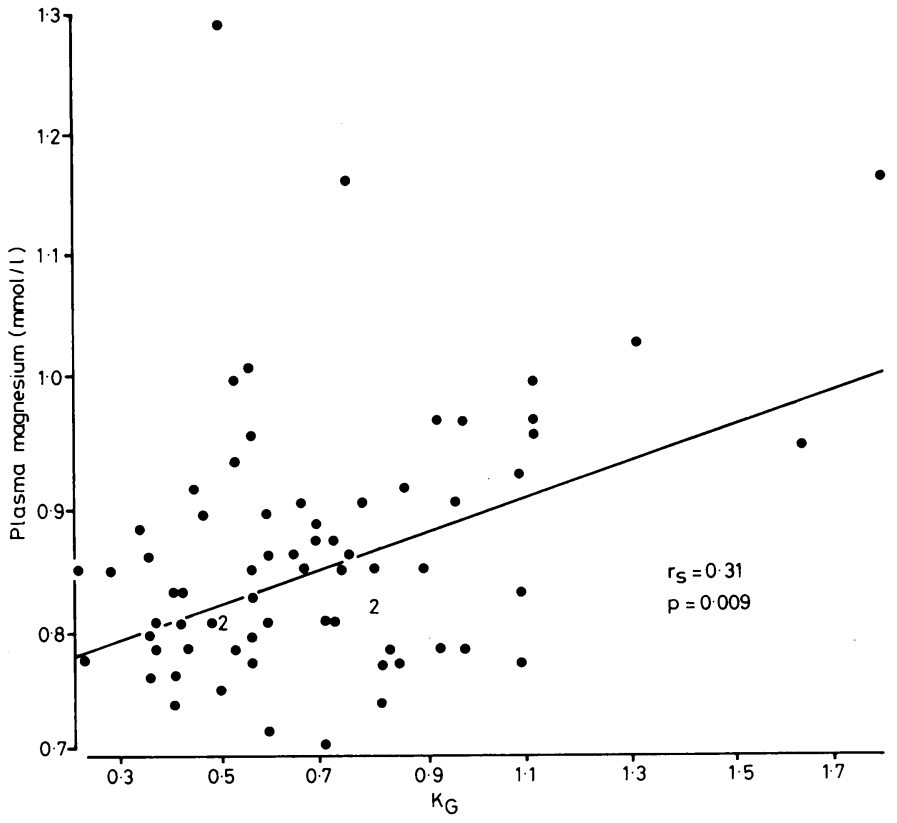

Plot of $K_{G}$ against fasting magnesium values in insulin dependent and non-insulin-dependent diabetics.

Conversion: SI to traditional units-Magnesium: $1 \mathrm{mmol} / 1 \approx 2.4 \mathrm{mg} / 100 \mathrm{ml}$.

\section{Discussion}

Plasma magnesium concentrations have been reported to be lower, ${ }^{56}{ }^{9}$ similar, ${ }^{21}$ or higher ${ }^{22}$ in diabetic than in non-diabetic subjects. We found no significant difference in plasma magnesium concentrations between the non-diabetic controls and all the diabetic subjects taken together. There were significant differences, however, when insulin treated and non-insulintreated diabetics were considered separately. Insulin treated diabetics had lower and non-insulin-treated diabetics higher plasma magnesium concentrations than non-diabetic subjects. Among the diabetics plasma magnesium concentration was related directly to age, and men had significantly higher concentrations than women in the non-insulin-treated group. Greater age and male preponderance possibly contributed to the higher plasma magnesium concentrations in our noninsulin-treated diabetic group.

Our findings confirm for fasting morning samples the inverse relation between the plasma concentrations of magnesium and glucose previously observed in random clinic samples ${ }^{6}$ as well as throughout the diurnal cycle. ${ }^{13}$ We also found a strong and inverse relation between plasma concentrations of magnesium and $\mathrm{HbA}_{1 \mathrm{c}}$. The inverse relation between magnesium and the concentrations of 3-hydroxybutyrate and acetoacetate probably reflects the association of a higher plasma magnesium value with better general metabolic control.

A direct relation was observed between the fasting plasma magnesium concentration and the rate of disappearance of intravenously injected glucose. Arguably these related features were both consequences of the severity of hyperglycaemia, with higher urinary losses of magnesium in the more hyperglycaemic and so lower plasma magnesium concentrations in those with the lower $\mathrm{K}_{\mathrm{G}}$ values. The correlation between plasma magnesium and $\mathrm{K}_{\mathrm{G}}$, however, was even stronger among those with a fasting glucose concentration below $7.0 \mathrm{mmol} / 1(126 \mathrm{mg} / 100 \mathrm{ml})$ $\left(r_{\mathrm{s}}=-0.53 ; \mathrm{p}<0.01\right)$, refuting that possibility.

The relation with glucose disappearance rate may be because higher plasma magnesium values are linked with either greater insulin secretion by the pancreatic $\beta$ cells in response to the glucose stimulus or increased sensitivity of the tissues to the hypoglycaemic action of insulin. The inverse relation between fasting magnesium and insulin, and even more the lack of relation between the plasma magnesium concentration and the 
total insulin secretion in the intravenous glucose tolerance tests, argue against a prime link with insulin supply. The relation of plasma magnesium persisted with the $K_{G}$ rate constant but not with the fasting blood glucose value when interactions between the latter two were allowed for, which further supports an effect mediated by glucose disposal. A factor expressing the resistance to the action of insulin in lowering blood glucose concentrations may be calculated, ${ }^{19}$ and this correlated strongly and inversely with the plasma concentration of magnesium $\left(r_{s}=-0.36 ; p<0.01\right)$. This gives direct support to emphasis on an improvement of the sensitivity of tissues to the action of available insulin in explaining how magnesium acts.

If a fault in diabetes mellitus were to impair the usual intracellular binding of magnesium the plasma magnesium concentration would tend to increase, depending on both the renal handling of magnesium and the total body magnesium value. When extracellular magnesium is high the efflux from cells would diminish, lessening the reduction in intracellularly active magnesium; this might explain the higher glucose disappearance rate.

Insulin resistance makes a variable but significant contribution to the pathogenesis of non-insulin-dependent diabetes mellitus. This resistance may reside at receptor or postreceptor level. Ionic imbalance of the type we describe might contribute significantly to postreceptor resistance. The increased rate of disposal of intravenously injected glucose, when the plasma magnesium concentration is higher, is compatible with the role of magnesium as a cofactor in glucose transporting mechanisms of the cell membrane ${ }^{2}$ and important intracellular enzymes of carbohydrate metabolism-for example, pyruvate dehydrogenase. It also accords with (but does not necessarily explain) the glucose intolerance of malnutrition and of diuretic treatment, in either of which there may be hypomagnesaemia. ${ }^{23}{ }^{24}$ It is probably relevant that glucose intolerance of these two conditions is said to be due to relative insulin resistance. In a recent review glucose intolerance was considered to be a disadvantage of diuretic treatment additional to potassium and magnesium abnormalities ${ }^{23}$; perhaps it should rather be considered as another expression of these ionic imbalances.

This implication of magnesium as an important factor in glucose metabolism might at least partially explain its postulated role in diabetic retinopathy and large vessel disease. Cardiovascular disease is a major cause of illness and death in diabetics, and it is intriguing to speculate whether the elemental disturbance described here reflects an abnormality similar to that linking heart disease with softness of the local water supply, where tissue magnesium concentrations may be lowered as a result of reduced intake.

Magnesium supplementation improves blood pressure control $^{25}$ and retention of concomitantly administered potassium supplements in patients receiving diuretics. ${ }^{26}$ One of the most abundant of earth's metallic elements and quantitatively the fourth most plentiful cation in vertebrates, magnesium may have wider metabolic implications than suspected hitherto. It will be important to determine whether oral magnesium supplementation of diabetics increases plasma magnesium concentrations and whether this will lower the $\mathrm{K}_{\mathrm{G}}$ rate constant.

Dr R M Hillson gave much help in collecting some of the blood samples. We thank Mrs B Pim for nursing care and clinical measurements; Mrs H Dhar, Mrs S Humphreys, and Mr R Jelfs for analytical work in the laboratory; Dr R H Wilkinson and staff of the department of clinical biochemistry, John Radcliffe Hospital, for blood glucose measurements; Miss V Beckett for statistical analysis; and Mrs D Renton for secretarial help.

CSY has been generously supported as a fellow of the Birla Smarak Kosh, Bombay Hospital, Bombay. We are also grateful for liberal support from the Oxford Diabetes Trust and the British Diabetic Association.

\section{References}

1 Aikawa JK. Magnesium: its biologic significance. Florida, USA: CRC Press Inc, 1981.

2 Goldman J, Fisher V. Magnesium is required in addition to calcium for insulin stimulation of glucose transport. In: The Endocrine Society: abstracts of 65th annual meeting, San Antonio, Texas, 1983. Baltimore, Md: Endocrine Society, 1984:271.

${ }^{3}$ Lehninger AS. Role of metal ions in enzyme systems. Physiol Rev 1950; 30:393-429.

4 Wacker WEC, Parisi AF. Magnesium metabolism. N Engl f Med 1968; 278:658-62.

5 Stutzman FL, Amatuzio DS. Blood serum magnesium in portal cirrhosis and diabetes mellitus. $\mathcal{F}$ Lab Clin Med 1953;41:215-9.

6 Mather HM, Nisbet J, Burton GH, et al. Hypomagnesemia in diabetes. Clin Chim Acta 1979;95:235-42.

${ }^{7}$ McNair P, Christensen MS, Christiansen C, et al. Renal hypomagnesaemia in human diabetes mellitus: its relation to glucose homeostasis. Eur $\mathfrak{F}$ Clin Invest $1982 ; 12: 81-5$.

${ }^{8}$ Fujii S, Takemura T, Wada $\mathrm{M}$, et al. Magnesium levels in plasma, erythrocyte and urine in patients with diabetes mellitus. Horm Metab Res 1982;14:161-2.

${ }^{9}$ McNair P, Christiansen C, Madsbad S, et al. Hypomagnesemia, a risk factor in diabetic retinopathy. Diabetes 1978;27:1075-7.

10 Moles KW, McMullen JK. Insulin resistance and hypomagnesaemia. Br Med F 1982;285:262.

11 Anderson TW, Neri LC, Schreiber G, Talbot FDF, Zdrejewski A. Ischaemic heart disease, water hardness and myocardial magnesium. Can Med Assoc $f$ 1975;113:199-203.

12 Marier JR. Cardio-protective contribution of hard waters to magnesium intake. Rev Can Bicl 1978;37:115-25.

13 Mather HM, Levin GE, Nisbet JA, et al. Diurnal profiles of plasma magnesium and blood glucose in diabetes. Diabetologia $1982 ; 22: 180-3$.

14 Ward NI, Ryan DE. Trace analysis of blood by neutron activation analysis. Analytica Chimica Acta 1979;105:185-97.

15 Alberti KGMM, Record CO, Williamson DH, et al. Metabolic changes in active chronic hepatitis. Clin $S_{c i} 1972 ; 42: 591-605$.

16 Albano JDM, Ekins RP, Maritz G, et al. A sensitive, precise radioimmunoassay of serum insulin relying on charcoal separation of bound and free hormone moieties. Acta Endocrinol (Copenh) 1972;70:487-509.

17 Jeppsson JO, Franzen B, Gaal AB. Simplified determination of $\mathrm{HbA}_{1} \mathrm{c}$ in diabetic patients by use of electrofocusing. In: Radola BJ, ed. Electrophoresis 1979: advanced methods, biochemical and clinical applications. Berlin, New York: Walter de Gruyte \& Co, 1980:655-61.

18 Conard V, Franckson JRM, Bastenie PA, et al. Etude critique du triangle d'hyperglycémie intraveineux chez l'homme normal et détermination d'un coefficient d'assimilation glucidique. Archives Internationales de Pharmacodynamie 1953;93:277-92.

19 Turner RC, Holman RR, Matthews DR, et al. Insulin deficiency and insulin resistance interaction in diabetes: estimation of their relative contribution by feedback analysis from basal plasma insulin and glucose concentrations. Metabolism 1979;28:1086-96.

${ }^{20}$ Mie NH, Hadonaihull C, Jenkins JG, Steinbrenner K, Bent DH. Statistical package for the social sciences. New York: McGraw-Hill, 1975.

${ }^{21}$ De Leeuw I, Vertommen J, Abs R. The magnesium content of the trabecular bone in diabetic subjects. Biomedicine [Express] 1978;29: 16-7.

${ }^{22}$ Beckett AG, Lewis JG. Serum magnesium in diabetes mellitus. Clin Sci $1959 ; 18: 597-604$.

23 Swales J. Magnesium deficiency and diuretics. Br Medf 1982;285:1377-8.

24 Prasad AS. Trace elements and iron in human metabolism. Chichester: John Wiley \& Sons, 1978:159-81.

${ }^{25}$ Dyckner T, Wester PO. Effect of magnesium on blood pressure. Br MedF $1983 ; 286$ : $1847-9$.

${ }^{26}$ Dyckner T, Wester PO. Relation between potassium, magnesium and cardiac arrhythmias. Acta Med Scand 1981 ;suppl 647:163-9.

(Accepted 31 January 1984) 